\title{
Impact of nose radius and machining parameters on surface roughness, tool wear and tool life during turning of AA7075/SiC composites for green manufacturing
}

\author{
Rajesh Kumar Bhushan
}

\begin{abstract}
Green manufacturing demands least wastage. Minimum chip formation reduces adverse effect on environment. Nose radius has a major role in reducing development of chips. Selection of proper nose radius and machining parameters will reduce amount of chip, therefore protect the environment. In finish turning of Al alloy-SiC, nose radius wear mainly affect the surface feature of the final product. It is owing to the direct contact between the area of tool nose and the SiC particles during turning. This paper is focused on influence of tool nose radius and machining parameters on surface quality of AA7075/15 wt.\% SiC (20 - $40 \mu \mathrm{m})$ composites and tool life of tungsten carbide inserts while dry turning. Response surface method (RSM) was utilized to find the roughness and tool life under numerous turning situations. Considering the single objective optimization of turning parameters, minimum roughness of $2.088 \mu \mathrm{m}$, was achieved at nose radius of $1.2 \mathrm{~mm}$ and maximum tool life of $6.72 \mathrm{~min}$, was obtained at nose radius of $0.4 \mathrm{~mm}$. Multi objective optimization by desirability analysis for minimum roughness and the maximum life of tool has shown that suitable value of nose radius is $0.4 \mathrm{~mm}$. Multi objective optimization of both roughness of surface and life of tool results in $1.81 \%$ increase in surface roughness and $10.11 \%$ decrease in tool life. Abrasion was mainly found to be responsible for wear of tungsten carbide inserts, while turning of AA7075/15 wt.\% SiC (20 - $40 \mu \mathrm{m})$ composites. Novelty of this research work is that so far no one has investigated impact of nose radius and machining parameters on surface roughness, tool wear and tool life during turning of AA7075/15 wt.\% SiC composites. Outcome of this research work will be useful for vehicle, aeroplane, space and ship industry.
\end{abstract}

Keywords: Nose radius, Tool life, Surface roughness, Al alloy-SiC composites, RSM green manufacturing

\section{Introduction}

Green manufacturing desires minimum wastage of materials. It increases productivity, and improve quality of products. Which reduces cost of production. Tool failure is mainly responsible for unpredictable downtime of turning process. Tool failure rises production duration and cost. This problem can be minimized by following a

Correspondence: rkbnitm@gmail.com

Department of Mechanical Engineering, National Institute of Technology Manipur, Imphal, India

\section{Springer Open}

scientific approach (Benardos and Vosniakos 2003). Tool nose radius affect the surface finish. When nose is too sharp the roughness of surface will be high and tool life will reduce. If other factors like material of work, turning speed, and coolant are not taken into consideration, better surface finish will be obtained by tool of large nose radius. This will also allow faster feed rate. According to Suresh 2002 turning tests had shown that large nose radius results in better tool life. This will also permit higher turning speed. A very large nose radius results in

(c) The Author(s). 2020 Open Access This article is licensed under a Creative Commons Attribution 4.0 International License, which permits use, sharing, adaptation, distribution and reproduction in any medium or format, as long as you give appropriate credit to the original author(s) and the source, provide a link to the Creative Commons licence, and indicate if changes were made. The images or other third party material in this article are included in the article's Creative Commons licence, unless indicated otherwise in a credit line to the material. If material is not included in the article's Creative Commons licence and your intended use is not permitted by statutory regulation or exceeds the permitted use, you will need to obtain permission directly from the copyright holder. To view a copy of this licence, visit http://creativecommons.org/licenses/by/4.0/. 
chatter. Surface roughness due to preceding revolution while turning, is eliminated in succeeding rotations. Machining of AA7075/15wt.\% SiC composite, to reduce roughness and maximize the tool life is still a challenge. There is urgent need to find the solutions to this challenge. Nose radius is a critical element in determining the value of surface roughness and tool life. Hence further research is necessary.

Initially literature review upto year 2020 is presented. This is followed by objectives of present research, novelty of the research work and important types of tool wear. Experimental work includes; details about Materials, machines, tools and Designs of Experiments. Finally results are explained and discussed.

\section{Literature review}

Investigation of surface characteristics and dimensions of component during machining really needed attention, because surface characteristics and dimensions influence the working of the components (Risbood et al. 2003). Worn cutting tool can be distinguished from an unworn cutting tool by monitoring the profile of workpiece (Mannan et al. 2000). Choudhury and Bartarya 2003 concluded that surface roughness decreased with increase in flank wear. Pavel et al. 2005, found that profile of component is replica of the tool edge profile. As per their observation increase in flank wear land width $\left(\mathrm{V}_{\mathrm{BB}}\right)$ resulted in decrease in roughness. Whereas increase in notch wear increased roughness. They found that notch wear and flank wear affect the surface roughness. However, Wong et al. 1997 observed that flank wear land width and surface roughness are not correlated. Kwon and Fischer 2003 proposed a tool wear index (TWI) to find out the roughness. But in the TWI roughness is a function of time. Roughness increases with period of machining. This differs with the observations of [Choudhury and Bartarya 2003; Pavel et al. 2005; Wong et al. 1997]. Kassim et al. 1999 stated that tool wear, based on the machining condition, affect roughness. Wong et al. 1997 stated that flank wear is not a dependable parameter to forecast roughness. Impact of cutting edge radius on surface roughness and tool wear was examined. CBN, cutting tools with nominal edge radius, 20, 30, and $40 \mu \mathrm{m}$, were used. Cutting edge radii were characterized with optical microscope. Variation of edge radius was calculated. Experiments were performed to assess effect of cutting edge radius on surface quality and tool wear under different machining conditions. Three-level and two-factor experiments were planned in test. Variations tend to be smaller with rise of nominal value of edge radius. Moreover, results showed that edge radii have a considerable effect on surface roughness and tool wear. Considering all factors, cutting tool with nominal edge radius of $30 \mu \mathrm{m}$ shows better machining performance among three groups of cutting tool in hard turning of AISI52100 steel (Zhao et al. 2017). Influence of cutting speed, feed rate, and tool nose radius on machined surface roughness, microhardness, and degree of work hardening of Inconel 718, were examined. Dry turning tests were conducted using three different cutting speeds, three different feed rates, and two cutting tools with different nose radius. Results showed that feed rate and tool nose radius have dominant influence on machined surface roughness. Degree of work hardening was strengthened as cutting speed and feed rate increased. Still, degree of work hardening decreased considerably when larger tool nose radius was used (Hua and Liu 2018). Impact of cutting speed, feed, depth of cut and tool nose radius on cutting temperature, surface roughness and cutting force were examined for turning of Ti-6Al-4 V (ELI). Mathematical models for cutting temperature, surface roughness and cutting force were established from experimental data using RSM. ANOVA test was conducted to assess contribution of parameters. Developed model was interfaced with particle swarm optimization to minimize responses (Shah and Bhavsar 2020). To understand impacts of cutting edge microgeometries on surface integrity, experimental were conducted for a varied range of cutting tool geometries and feeds. Scanning laser interferometry was used in conjunction with profile-analysis algorithm to analyse, characterize, and verify geometry of complex cutting edge micro-geometries. Near surface nanostructure, and surface roughness of produced surfaces were characterized and correlated to varied tool geometries. Scanning laser interferometry examination of surfaces revealed that large hones provided either an increase or decrease in roughness, depending on expected kinematic roughness (Brown and Schoop 2020). Finish dry hard turning (FDHT) of hardened AISI grade die steel D3 was done by PVD-TiN coated (Al2O3-TiCN) mixed ceramic tool insert. Contribution to modeling and optimization of parameters (cutting force, surface roughness, and tool wear) for machinability evaluation was find out. Turning trials were conducted based on Taguchil's L18 orthogonal array design of experiments. Regression model was developed, also adequate model prediction was made by considering tool approach angle, nose radius, cutting speed, feed rate, and depth of cut (Panda et al. 2020).

Above literature review show that research work has been done about impact of nose radius on various grades of steels, while machining. Therefore research gaps are; investigation about the importance of nose radius during turning of AA7075 / SiC composite, investigation about effect of nose radius and machining parameters on surface roughness of AA7075 / SiC, wear and life of carbide tools. The present work is different from other researcher's work in a way that so far no one has 
investigated the impact of nose radius and machining parameters on surface roughness and tool life during turning of AA7075 /15 wt.\% SiC (particle size 20 to $40 \mu \mathrm{m})$. This research work has been taken up with the following objectives.

\section{Objectives of present research}

i. Measurement of surface roughness and tool life of work piece.

ii. Investigating the influence of nose radius on the roughness and tool life.

iii. Prediction of nose radius for minimum roughness and maximum life of tool using RSM.

iv. Multi objective optimization through desirability analysis for the minimum roughness and the maximum tool life to predict suitable value of nose radius.

v. Study the wear of tool nose.

\section{Novelty of the research work}

Turning of AA7075/15 wt\% $\mathrm{SiC}(20-40 \mu \mathrm{m})$ composites is very challenging. Selection of proper tool material and geometry is very essential. Tool with high nose radius will provide surface finish and facilitate higher feed rate, but it will reduce the tool life. Hence research is necessary to find out optimum value of nose radius and machining parameters to minimize surface roughness and maximize tool life.

\section{Important types of tool Wear}

Figures 1a-b represent flank, nose, crater and notch wear. So far flank wear and crater wear are investigated as per ISO 3685 standard (ISO 3685 1993).

Flank wear occurs due to abrasion. Flank wear decreases accuracy of machined parts, because it results in damage of the cutting tool (Stephenson and Agapiou 1997). Flank wear land width $\left(\mathrm{V}_{\mathrm{BB}}\right)$ displayed in Fig. 1b, is used to decide tool life.

Crater wear creates a crater on face of the tool. This is due to striking of $\mathrm{SiC}$ particles. Notch wear occurs due to reaction between tool faces and coolant (Stephenson and Agapiou 1997). Notch wear growth on the tool face causes damage of the cutting tool. Severe nose wear may result in sudden tool failure (Dimla 2000). Wear in nose area is due to flank wear and notch wear (Dimla 2000;

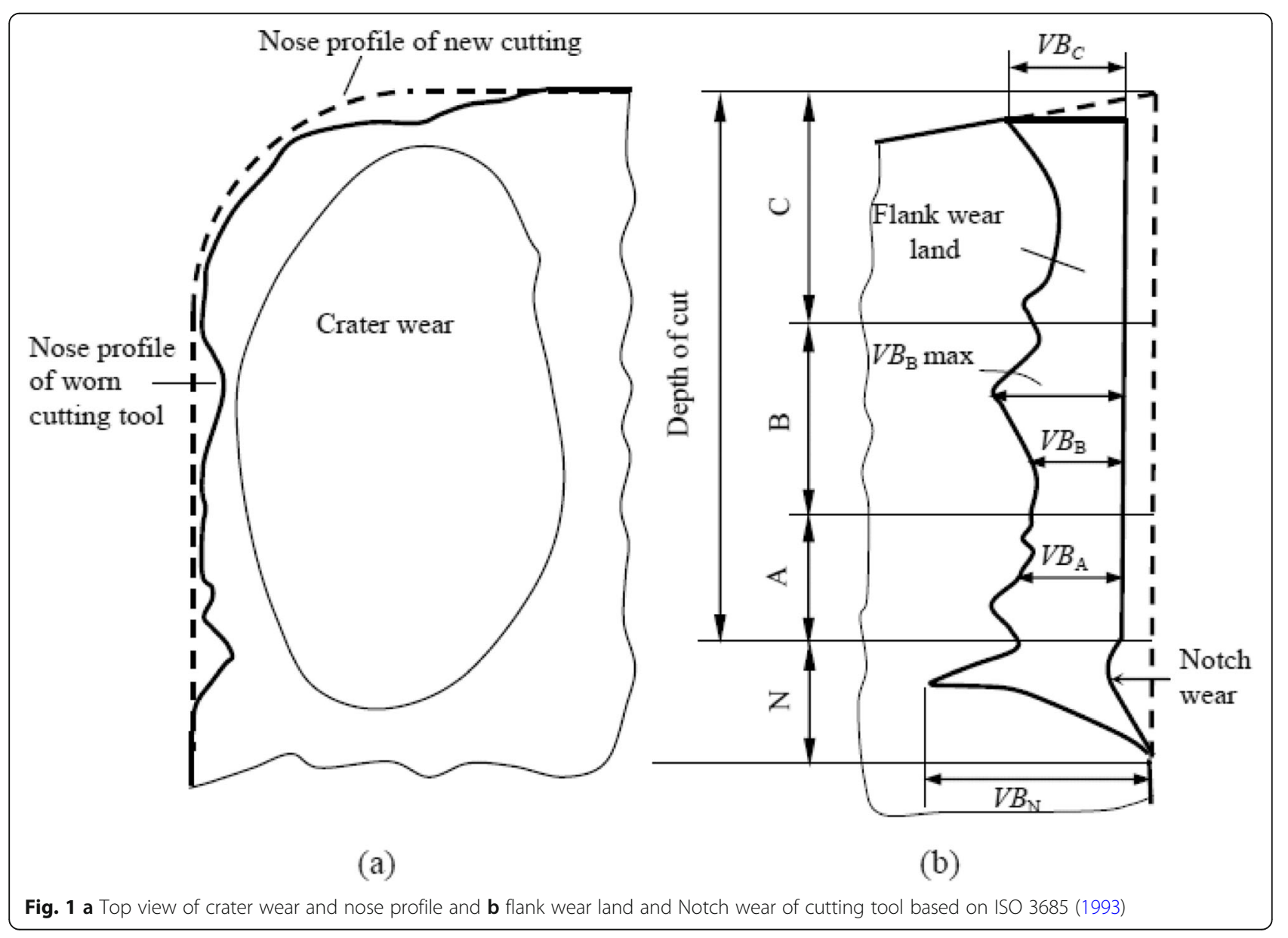


Jurkovic et al. 2005). Figure 1a shows them. Kwon and Fischer 2003, reported that in turning operation, nose wear affects the surface of component.

\section{Experimental work Materials}

AA7075/15 wt.\% SiC composite were selected for machining investigation. Composition of $7075 \mathrm{Al}$ alloy is tabulated in Table 1. Composite AA7075/15 wt.\% SiC was made by stir casting process (bhushan and kumar 2011).

\section{Machining}

CNC Turning Machine (Model TC 20) was used for conducting the experiments. Figure 2 shows this machine. Parameters are tabulated in Table 2.

\section{Process parameters}

As per literature review, cutting speed, feed, depth of cut and nose radius were taken as process parameters. Responses were surface roughness and tool life. Range of process parameters was finalized based on pilot experiments. These are tabulated in Table 3 (Bhushan 2013).

\section{Cutting tool}

Hardness of $\mathrm{SiC}$ of particle is $2700-3500 \mathrm{HV}$. Hardness of tungsten carbide inserts is $1500-1800 \mathrm{HV}$. If only plane tungsten carbide inserts are used, they cannot machine AA7075/ SiC composites. Hardness of titanium nitride is $2400-2800 \mathrm{HV}$. Hence titanium nitride coated tungsten carbide inserts were used. Inserts CNMG120404, 120,408 and 120,412 grade 6615 were used for turning of AA7075/15 wt\% SiC.

\section{Designs of experiments}

Design of experimentation technique viz. RSM was used for investigating the effect of four process parameters on surface roughness and tool life, while turning of AA7075/15 wt\% SiC composite. In RSM relationship between process parameters and responses is achieved with the various desired criteria. Importance of process parameters on the coupled response was also find out (Myers and Montgomery 1995). Thirty numbers of experiments were conducted as per, face centered central composite design (FCCCD) for four variables at three levels. These are depicted in Table 4.

Table 1 Composition (wt\%) of Al alloy 7075

\begin{tabular}{llllllll}
\hline Material & $\mathrm{Zn}$ & $\mathrm{Mg}$ & $\mathrm{Cu}$ & $\mathrm{Cr}$ & $\mathrm{Si}$ & $\mathrm{Fe}$ & $\mathrm{Al}$ \\
\hline $\mathrm{Wt} \%$ & 5.62 & 2.52 & 1.63 & 0.22 & 0.06 & 0.18 & balance \\
\hline
\end{tabular}

Turning of [AA7075/15 wt.\% SiC (20-40 $\mu \mathrm{m})]$ composite Experiments were conducted on CNC. AA7075/15 wt.\% SiC. $30 \mathrm{~mm}$ diameter and $110 \mathrm{~mm}$ length rods were utilized for turning. External turning was done by tungsten carbide inserts. No coolant was used during turning. Roughness and tool life were measured. ANOVA was conducted. Significant process parameters were identified and their interaction effects were studied. Experimental results for turning of AA7075/15 wt.\% SiC are tabulated in Table 4 . These are the average values of three readings. Wear of inserts was measured from SEM microstructure. Tool life was calculated from wear of inserts.

\section{Methods for evaluating the machining data Surface roughness}

Gippan SRT - 6210 (Fig. 3) was used for measurement of surface roughness. Cut-off $=0.8 \mathrm{~mm}$, sampling lengths $=4$ $\mathrm{mm}$ and driving speed of stylus $=0.5 \mathrm{~mm} / \mathrm{rev}$ was taken. ISO 4287 standard was used (ISO 4287 1997).

\section{Tool life}

ISO 3685 specifies a flank wear width of $0.76 \mathrm{~mm}$ for rough turning and $0.38 \mathrm{~mm}$ for fine turning (ISO 3685 1993). After turning inserts were examined by SEM. Duration of machining as per above specifications was taken as the tool life.

\section{Results}

\section{Metallographic examination}

Scanning electron microstructure (SEM) of AA7075 is shown in Fig. 4. Grains are distributed uniformly. Grain distribution is dendritic at few places. Higher stirring speed and shorter period during processing produced smaller grains (Moon 1990).

Figure 5 shows the microstructure of AA7075/15 wt.\% $\mathrm{SiC}$ composite. In this structure, $\mathrm{SiC}$ particles are uniformly distributed in the AA7075 matrix, without indicating any porosity.

\section{Effect of process parameters on responses}

Thirty experiments were designed by using FCCCD. These were conducted on CNC machine. Design Expert 2006 was used for selection of appropriate model and development of response surface models. Regression equations were obtained for surface roughness and tool life. Response were plotted to investigate the effect of input process parameters with their second order interactions on response characteristics.

\section{Selection of adequate model}

Tables 5 and 6 displays various tests to select the proper models to fit for surface roughness, and tool life. For all 


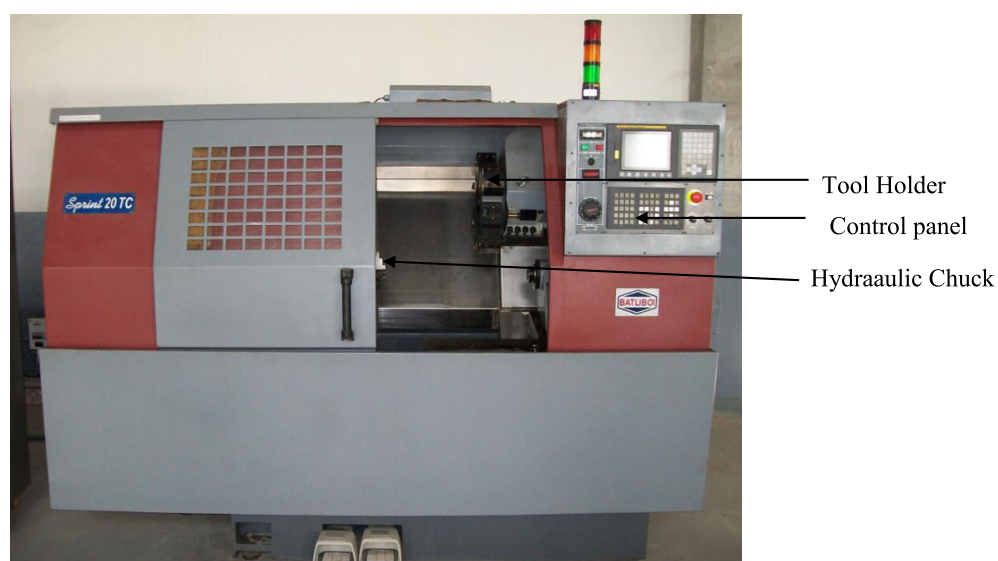

Fig. 2 CNC Turning Machine

the responses, the quadratic model is appropriate (Prob> $\mathrm{F}$ values are less than 0.05 in all the cases).

\section{Analysis of variance}

ANOVA was done to statistically analyze the results. Pooled version of ANOVA for surface roughness, and tool life are given in Tables 7 and 8. Results show that for surface roughness, cutting speed (A), feed (B), depth of cut $(C)$, nose radius (D), quadratic terms $\left(B^{2}\right)$ and interaction term $(\mathrm{CD})$ are significant terms. For tool life cutting speed (A), feed (B), depth of cut (C), nose radius (D), the quadratic terms $\left(C^{2}, D^{2}\right)$ and interaction terms $(\mathrm{BD}, \mathrm{CD})$ are significant model terms.

\section{Second order regression coefficient}

Experimental data (Table 4) was utilized to obtain second order regression coefficient. Insignificant coefficients terms (based on ANOVA) were omitted from the equations.

$$
\begin{aligned}
\text { Surface roughness }= & +7.99664-5.24444 \mathrm{E}-003 * \mathrm{~A}-60.60667 * \mathrm{~B} \\
& +3.67882 * \mathrm{C}+0.2845 * \mathrm{D} \\
& +165.17778 * \mathrm{~B}^{2}-1.94922 * \mathrm{C} * \mathrm{D}
\end{aligned}
$$

Table 2 CNC parameters

\begin{tabular}{ll}
\hline Parameter & Specifications \\
\hline Center to center distance & $575 \mathrm{~mm}$ \\
Swing & $500 \mathrm{~mm}$ \\
Spindle speed & $40-4000 \mathrm{rpm}$ \\
Accuracy & \\
$\quad$-axis & $+/-0.005 \mathrm{~mm}$ \\
Z-axis & $+/-0.0075 \mathrm{~mm}$ \\
Spindle motor & $7.5 \mathrm{KW}$ \\
\hline
\end{tabular}

$$
\begin{aligned}
\text { Tool life }= & +12.82446-0.012963 * \mathrm{~A}-28.86111 * \mathrm{~B} \\
& +24.03875 * \mathrm{C}-15.18201 * \mathrm{D}-41.41129 * \mathrm{C}^{2} \\
& +4.95968 * \mathrm{D}^{2}+18.43750 * \mathrm{~B} * \mathrm{D} \\
& +5.07813 * \mathrm{C} * \mathrm{D}
\end{aligned}
$$

\section{Effect of process parameters on surface roughness}

Figure 6 a represents the surface plot of roughness v/s cutting speed and feed. Figure shows that the increase in cutting speed reduces the surface roughness. Increase in feed first decreases then increases the surface roughness.

Figure $6 \mathrm{~b}$ shows the effect of cutting speed and depth of cut on surface roughness. Increase in depth of cut increases the surface roughness in turning of AA7075/ $15 \mathrm{wt} . \% \mathrm{SiC}(20-40 \mu \mathrm{m})$. Better surface roughness could be obtained only at lower value of depth of cut. Figure 6c indicate the effect of cutting speed and nose radius on surface roughness. Surface roughness decreases with increase in nose radius. Chip thinning is because of reduction in feed or increase in tool nose radius. This phenomena results in elongation of chip in addition to the thinning effect. Machining with lower chip thickness generally leads to better surfaces.

Table 3 Parameters values

\begin{tabular}{lllll}
\hline Factors & Parameters & Level 1 & Level 2 & Level 3 \\
\hline A & Cutting speed $(\mathrm{m} / \mathrm{min})$ & 90 & 150 & 210 \\
B & Feed $(\mathrm{mm} / \mathrm{rev})$ & 0.15 & 0.2 & 0.25 \\
C & Depth of Cut $(\mathrm{mm})$ & 0.2 & 0.4 & 0.6 \\
D & Nose radius $(\mathrm{mm})$ & 0.4 & 0.8 & 1.2 \\
\hline
\end{tabular}


Table 4 Experimental Results - [AA7075/15 wt.\%sic (20-40 $\mu \mathrm{m})$ composite]

\begin{tabular}{|c|c|c|c|c|c|c|}
\hline Ex & Cutting speed $(\mathrm{m} / \mathrm{min})$ & Feed $(\mathrm{mm} / \mathrm{rev})$ & Depth of Cut (mm) & Nose radius (mm) & Surface roughness $(\mu \mathrm{m})$ & Tool life (min) \\
\hline 1 & 90 & 0.15 & 0.20 & 0.40 & 2.916 & 6.5 \\
\hline 2 & 210 & 0.15 & 0.20 & 0.40 & 2.256 & 6.0 \\
\hline 3 & 90 & 0.25 & 0.20 & 0.40 & 3.208 & 4.5 \\
\hline 4 & 210 & 0.25 & 0.20 & 0.40 & 2.706 & 2.5 \\
\hline 5 & 90 & 0.15 & 0.60 & 0.40 & 3.996 & 4.2 \\
\hline 6 & 210 & 0.15 & 0.60 & 0.40 & 3.302 & 1.3 \\
\hline 7 & 90 & 0.25 & 0.60 & 0.40 & 4.754 & 1.5 \\
\hline 8 & 210 & 0.25 & 0.60 & 0.40 & 3.747 & 0.8 \\
\hline 9 & 90 & 0.15 & 0.20 & 1.20 & 2.607 & 4.4 \\
\hline 10 & 210 & 0.15 & 0.20 & 1.20 & 2.113 & 2.5 \\
\hline 11 & 90 & 0.25 & 0.20 & 1.20 & 3.334 & 3.5 \\
\hline 12 & 210 & 0.25 & 0.20 & 1.20 & 2.847 & 1.5 \\
\hline 13 & 90 & 0.15 & 0.60 & 1.20 & 3.261 & 2.7 \\
\hline 14 & 210 & 0.15 & 0.60 & 1.20 & 2.759 & 1.1 \\
\hline 15 & 90 & 0.25 & 0.60 & 1.20 & 3.923 & 2.3 \\
\hline 16 & 210 & 0.25 & 0.60 & 1.20 & 3.176 & 0.6 \\
\hline 17 & 90 & 0.20 & 0.40 & 0.80 & 3.278 & 4.5 \\
\hline 18 & 210 & 0.20 & 0.40 & 0.80 & 2.707 & 3.8 \\
\hline 19 & 150 & 0.15 & 0.40 & 0.80 & 2.988 & 3.3 \\
\hline 20 & 150 & 0.25 & 0.40 & 0.80 & 3.421 & 2.1 \\
\hline 21 & 150 & 0.20 & 0.20 & 0.80 & 2.353 & 2.4 \\
\hline 22 & 150 & 0.20 & 0.60 & 0.80 & 3.052 & 1.2 \\
\hline 23 & 150 & 0.20 & 0.40 & 0.40 & 2.999 & 5.4 \\
\hline 24 & 150 & 0.20 & 0.40 & 1.20 & 2.299 & 3.1 \\
\hline 25 & 150 & 0.20 & 0.40 & 0.80 & 2.633 & 4.4 \\
\hline 26 & 150 & 0.20 & 0.40 & 0.80 & 2.648 & 4.3 \\
\hline 27 & 150 & 0.20 & 0.40 & 0.80 & 2.825 & 4.1 \\
\hline 28 & 150 & 0.20 & 0.40 & 0.80 & 2.869 & 3.7 \\
\hline 29 & 150 & 0.20 & 0.40 & 0.80 & 2.773 & 3.7 \\
\hline 30 & 150 & 0.20 & 0.40 & 0.80 & 2.818 & 3.6 \\
\hline
\end{tabular}

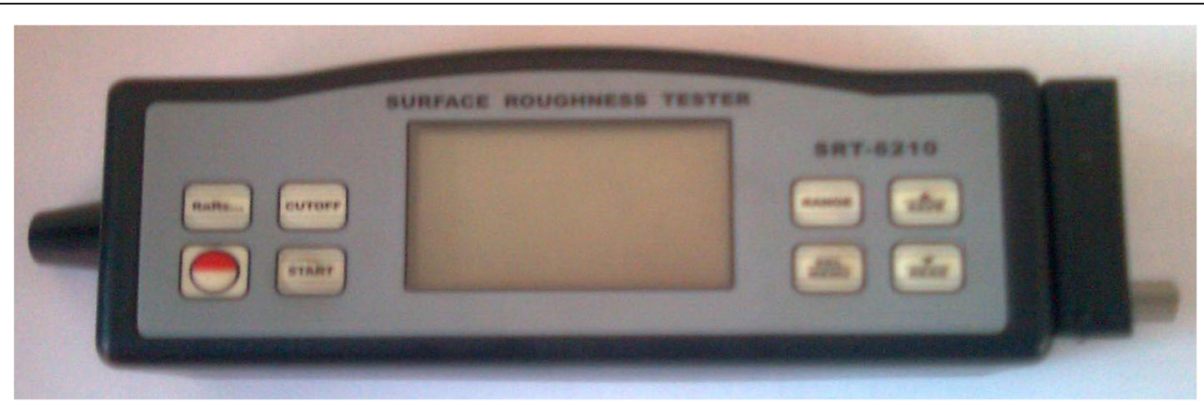

Fig. 3 Surface roughness tester 


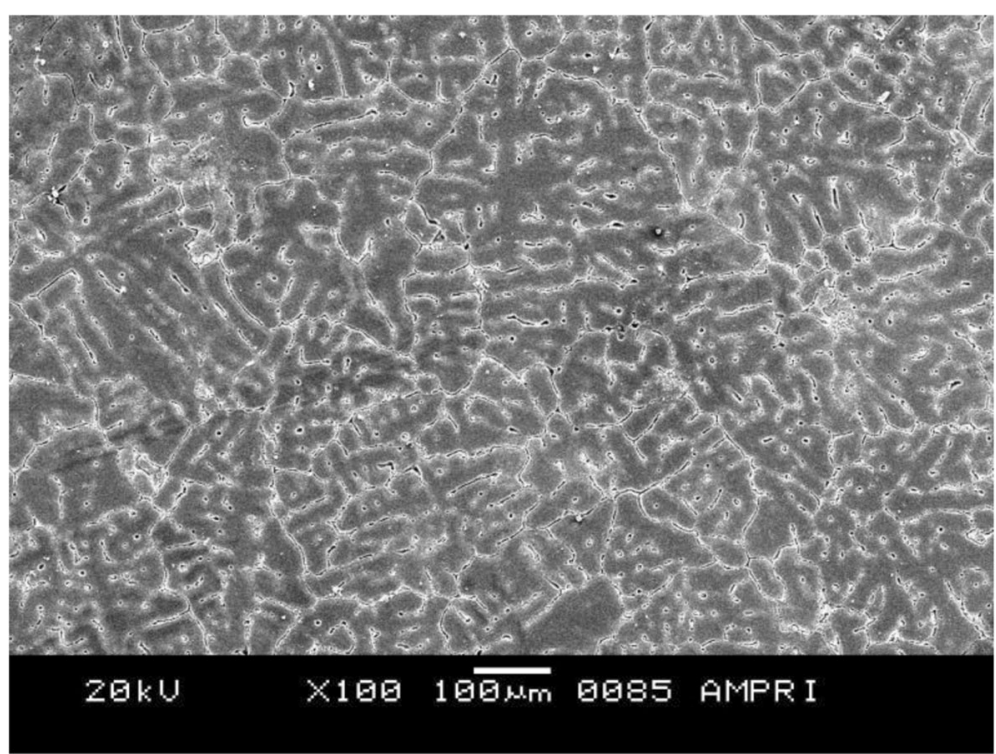

Fig. 4 Microstructure of $7075 \mathrm{Al}$ alloy

\section{Effect of process parameters on tool life}

Figure $7 \mathrm{a}$ shows plot of tool life $\mathrm{v} / \mathrm{s}$ cutting speed and feed. Tool life decreases with the increase in cutting speed. Increase in feed sharply decreases the tool life.

Figure 7b shows the effect of cutting speed and depth of cut on tool life. Increase in depth of cut first increases then decreases the tool life in machining of AA7075/ $15 \mathrm{wt} \% \mathrm{SiC}$. Figure $7 \mathrm{c}$ shows the effect of cutting speed and nose radius on tool life. From the figure, it is seen that the tool life reduces at high value of nose radius. Turning is to be carried out at lower value of cutting speed, feed and depth of cut to have the maximum tool life.

\section{Validation of regression model}

Two experiments (no 1 and 24) were selected out of 30 experiments. Regression equations were validated by comparing 03 experimental data with data obtained by putting the same experimental conditions in the regression equations. Comparison is tabulated in Table 9. There is close correlation between experimental data and data obtained by regression equation. Which validate the developed regression equations. There is 0.8 to $10 \%$ variation. This means 90 to 99.2 confidence level. Therefore model is accurate and satisfactory.

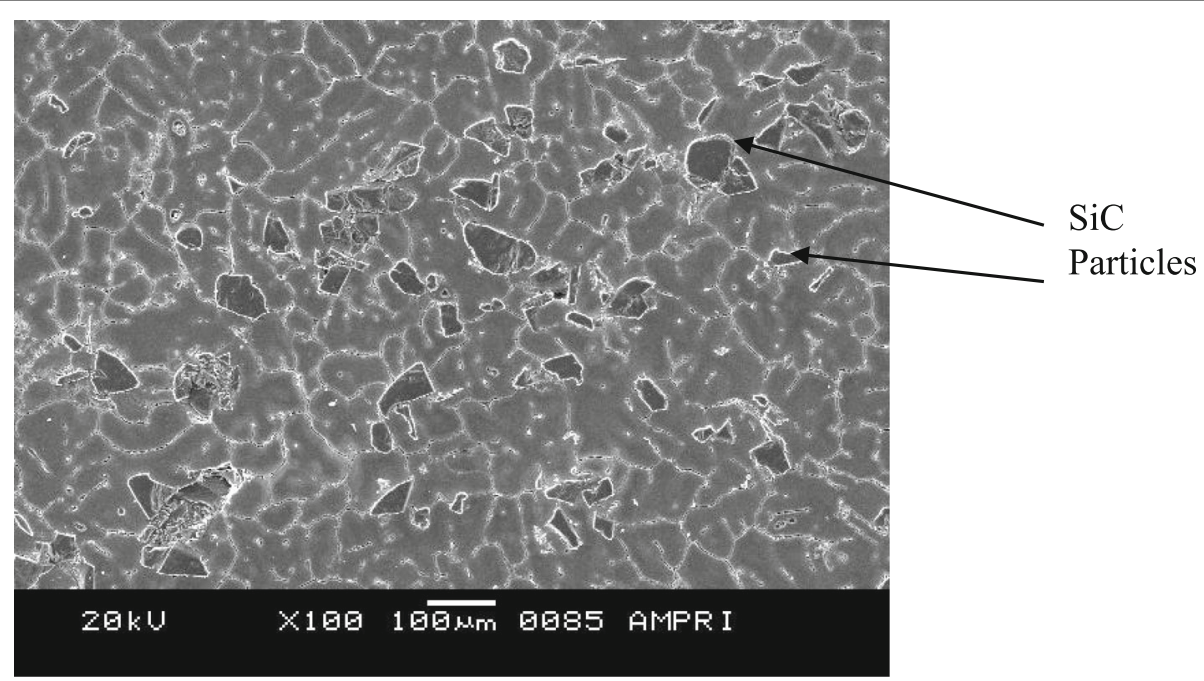

Fig. 5 Microstructure of AA7075/ 15 wt\% SiC (20-40 $\mu \mathrm{m})$ 
Table 5 Sequential Model Sum of Squares- Surface roughness

\begin{tabular}{|c|c|c|c|c|c|c|}
\hline Source & Sum of Squares & DF & Mean Square & F Value & Prob > F & \\
\hline Mean & 273.42 & 1 & 273.42 & & & \\
\hline Linear & 7.07 & 4 & 1.77 & 21.43 & $<0.0001$ & \\
\hline $2 \mathrm{FI}$ & 0.49 & 6 & 0.081 & 0.98 & 0.4655 & \\
\hline Quadratic & 1.36 & 4 & 0.34 & 24.49 & $<0.0001$ & Suggestec \\
\hline Cubic & 0.16 & 8 & 0.019 & 2.56 & 0.1168 & Aliased \\
\hline Residual & 0.053 & 7 & $7.612 \mathrm{E}-003$ & & & \\
\hline Total & 282.55 & 30 & 9.42 & & & \\
\hline
\end{tabular}

\section{Effect of nose radius}

SEM micrographs of tungsten carbide inserts before and after turning of AA7075/15 wt.\% SiC were taken. Inserts before turning are shown in Fig. 8. Inserts after turning are shown in Fig. 9. Micrographs in Fig. 9 are showing flank wear and crater wear under different machining conditions.

\section{Wear of tungsten carbide inserts used in experiments}

Figure 8 shows the rake face and flank face of tungsten carbide inserts of nose radius $0.4 \mathrm{~mm}, 0.8 \mathrm{~mm}$ and $1.2 \mathrm{~mm}$ before turning. Figure 9 gives the comparison of tungsten carbide inserts (rake face and flank face) after machining of nose radius $0.4 \mathrm{~mm}$ and $1.2 \mathrm{~mm}$ under same machining conditions i.e. Cutting speed $=90 \mathrm{~m} / \mathrm{min}$, Feed $=0.25 \mathrm{~mm} / \mathrm{rev}$, DOC $=0.6 \mathrm{~mm}$. Flank wear and Crater wear of carbide inserts with nose radius of $1.2 \mathrm{~mm}$ are more, as compared to nose radius $0.4 \mathrm{~mm}$.

SEM macrographs of worn out cutting wedges of tungsten carbide tool are shown in Fig. 9. It is seen that cutting tool of nose radius $=1.2 \mathrm{~mm}$ at Cutting speed $=$ $90 \mathrm{~m} / \mathrm{min}$, Feed $=0.25 \mathrm{~mm} / \mathrm{rev}$ and DOC $=0.6 \mathrm{~mm}$ have deeper nose distortion. Removal of insert material is also seen over the cutting edge. This is due to the combined action of cutting force and increase in temperature acting over the cutting edge.
Single response optimization solutions for composite

Range of input parameters and values of responses were taken from the experimental results tabulated in Table 4. Optimum solutions are as under;

\section{Surface roughness}

The optimum values of cutting speed, feed, depth of cut and nose radius to minimize surface roughness $(2.08877 \mu \mathrm{m})$ are $191.09 \mathrm{~m} / \mathrm{min}, 0.19 \mathrm{~mm} / \mathrm{rev}, 0.23 \mathrm{~mm}$, $1.19 \mathrm{~mm}$ respectively.

\section{Tool life}

Optimum values of cutting speed, feed, depth of cut and nose radius to maximum tool life $(6.72 \mathrm{~min})$ are $90.82 \mathrm{~m} / \mathrm{min}, \quad 0.16 \mathrm{~mm} / \mathrm{rev}, \quad 0.31 \mathrm{~mm}$ and $0.43 \mathrm{~mm}$ respectively.

\section{Multi response optimization \\ Desirability function approach}

Optimization of process parameters is necessary to achieve better productivity. In this research work, optimization was done to get minimum surface roughness and maximum tool life in turning of AA7075/15 wt.\% SiC $(20-40 \mu \mathrm{m})$ composites using developed mathematical model. Desirability function approach was used.

Table 6 Sequential Model Sum of Squares- Tool life

\begin{tabular}{|c|c|c|c|c|c|c|}
\hline Source & Sum of Squares & DF & Mean Square & F Value & Prob > F & \\
\hline Mean & 304.01 & 1 & 304.01 & & & \\
\hline Linear & 44.77 & 4 & 11.19 & 11.95 & $<0.0001$ & \\
\hline $2 \mathrm{FI}$ & 5.60 & 6 & 0.93 & 1.00 & 0.4557 & \\
\hline Quadratic & 12.72 & 4 & 3.18 & 9.39 & 0.0005 & Suggested \\
\hline Cubic & 2.65 & 8 & 0.33 & 0.96 & 0.5306 & Aliased \\
\hline Residual & 2.43 & 7 & 0.35 & & & \\
\hline Total & 372.19 & 30 & 12.41 & & & \\
\hline
\end{tabular}


Table 7 Pooled ANOVA-Surface roughness

\begin{tabular}{llllll}
\hline Source & Sum of squares & DF & Mean squares & F value & Prob $>F$ \\
\hline Model & 8.68 & 6 & 1.45 & $75.02^{*}$ & $<0.0001$ significant \\
A & 1.78 & 1 & 1.78 & $92.39^{*}$ & $<0.0001$ \\
B & 1.34 & 1 & 1.34 & $69.66^{*}$ & $<0.0001$ \\
C & 3.23 & 1 & 3.23 & $367.66^{*}$ & $<0.0001$ \\
D & 0.71 & 1 & 0.71 & $36.60^{*}$ & $<0.0001$ \\
B $^{2}$ & 1.23 & 1 & 1.23 & $63.65^{*}$ & $<0.0001$ \\
CD & 0.39 & 1 & 0.39 & $20.17^{*}$ & 0.0002 \\
Residual & 0.44 & 23 & 0.019 & 2.27 & 0.1851 not significant \\
Lack of Fit & 0.40 & 18 & 0.022 & & \\
Pure Error & 0.048 & 5 & $9.661 \mathrm{E}-003$ & & \\
Cor Total & 9.13 & 29 & & &
\end{tabular}

* Significant at 95\% confidence interval

Multi objective optimization of turning parameters to get minimum roughness and maximum tool life

Surface roughness was minimized and tool life was maximized through desirability analysis. Cutting parameters were allowed to vary from lower limit to upper limit. Constraints utilized for optimization of parameters are tabulated in Table 10. Surface roughness is given more importance than tool life, since industrial requirement in turning the AA7075/15 wt.\% $\mathrm{SiC}$ composite demands more emphasis on the minimum surface roughness than maximum time tool.

Multi objective optimization solutions for the minimum surface roughness and the maximum tool life are given in Table 11 . Solution 1 with desirability value of 0.877 is selected. In this, the optimum values of cutting speed, feed, depth of cut and nose radius are $148.05 \mathrm{~m} / \mathrm{min}, 0.16 \mathrm{~mm} / \mathrm{rev}, 0.23 \mathrm{~mm}$ and $0.40 \mathrm{~mm}$ respectively.
Figure 10 displays composite desirability of surface roughness and tool life. This value is gained by using Eqs. 1 and 2. Composite desirability value is 0.88 in Fig. 10. Which is suitable to get minimum surface roughness and the maximum tool life. Figure 11 displays the contour graph of surface roughness at maximum desirability value. In this figure predicted value of surface roughness is $2.55 \mu \mathrm{m}$, in the range of 2.113 to $4.754 \mu \mathrm{m}$ after the multi response optimization. Figure 12 displays the contour graph of tool life at maximum desirability value. In this figure predicted value of tool life is 6.04 $\mathrm{min}$, in the range of 0.6 to $6.5 \mathrm{~min}$, after the multi response optimization.

\section{Effect of multi response optimization of surface roughness and tool life}

Considering single objective optimization of cutting parameters, the value of surface roughness obtained is

Table 8 Pooled ANOVA- Tool life

\begin{tabular}{|c|c|c|c|c|c|}
\hline Source & Sum of squares & DF & Mean squares & F Value & Prob $>$ F \\
\hline Model & 62.21 & 8 & 7.53 & $19.82^{*}$ & $<0.0001$ significant \\
\hline A & 10.89 & 1 & 10.89 & $28.68^{*}$ & $<0.0001$ \\
\hline B & 8.96 & 1 & 8.96 & $23.60^{*}$ & $<0.0001$ \\
\hline$C$ & 18.20 & 1 & 18.20 & $47.93^{*}$ & $<0.0001$ \\
\hline D & 6.72 & 1 & 6.72 & $17.70^{*}$ & 0.0004 \\
\hline$C^{2}$ & 9.45 & 1 & 9.45 & $24.89^{*}$ & $<0.0001$ \\
\hline$D^{2}$ & 2.17 & 1 & 2.17 & $5.71^{*}$ & 0.0263 \\
\hline $\mathrm{BD}$ & 2.18 & 1 & 2.18 & $5.73^{*}$ & 0.0261 \\
\hline$C D$ & 2.64 & 1 & 2.64 & $6.95^{*}$ & 0.0154 \\
\hline Residual & 7.97 & 21 & 0.38 & 3.37 & 0.0701 not significant \\
\hline Lack of Fit & 7.38 & 16 & 0.46 & & \\
\hline Pure Error & 0.59 & 5 & 0.12 & & \\
\hline Cor Total & 68.18 & 29 & & & \\
\hline
\end{tabular}

* Significant at $95 \%$ confidence interval 


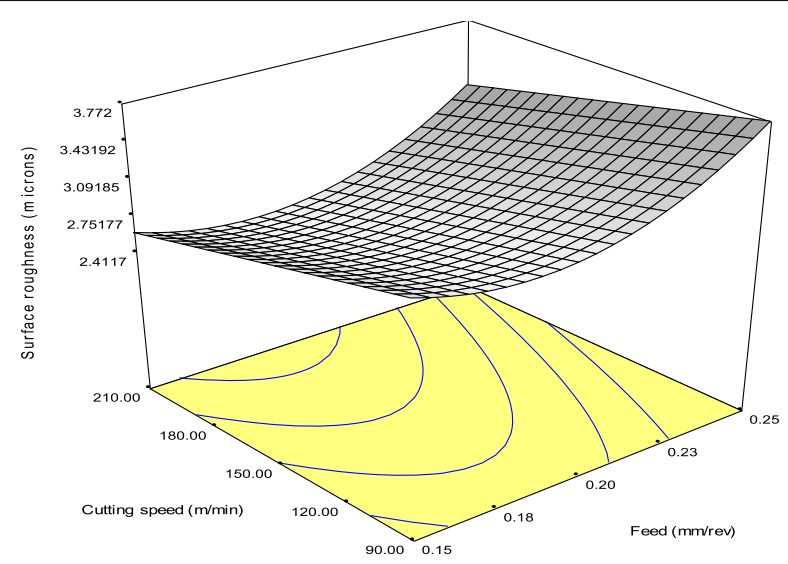

(a): Influence of Cutting Speed and Feed on Roughness

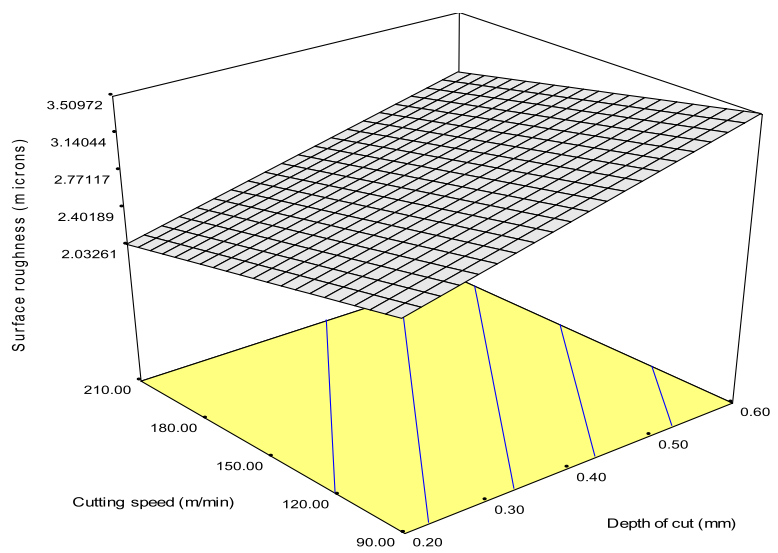

(b): Influence of Cutting Speed and Depth of Cut on Roughness

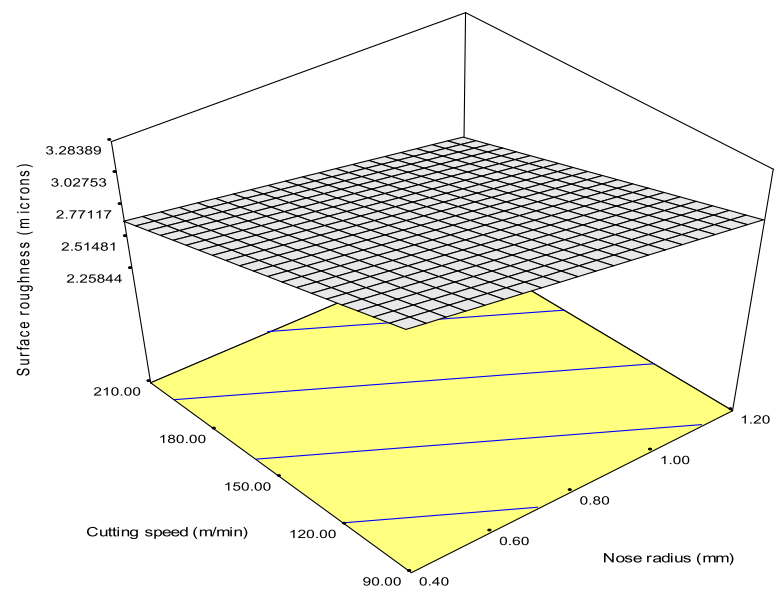

(c): Influence of Cutting Speed and Nose Radius on Roughness

Fig. $\mathbf{6}$ a Influence of Cutting Speed and Feed on Roughness. b Influence of Cutting Speed and Depth of Cut on Roughness. $\mathbf{c}$ Influence of Cutting Speed and Nose Radius on Roughness. a, b, c 3D Surface graph for Surface Roughness ( $\mu \mathrm{m})$ 


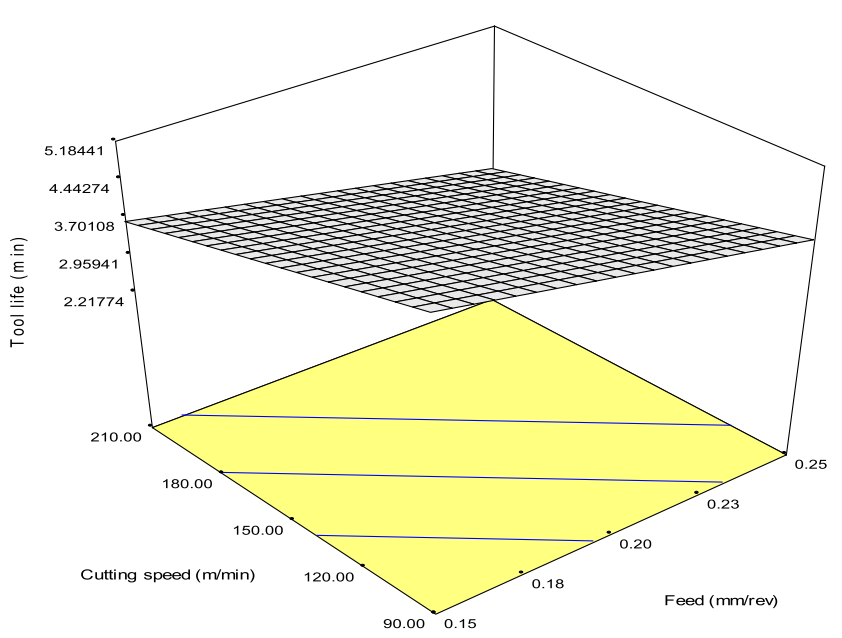

(a): Influence of Cutting Speed and Feed on Tool Life

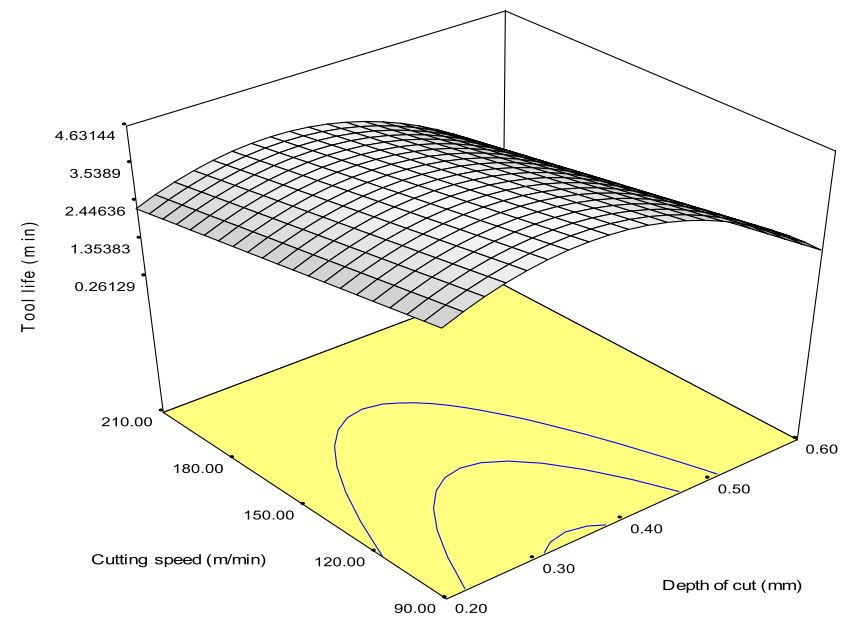

(b) Influence of Cutting Speed and Depth of Cut on Tool Life

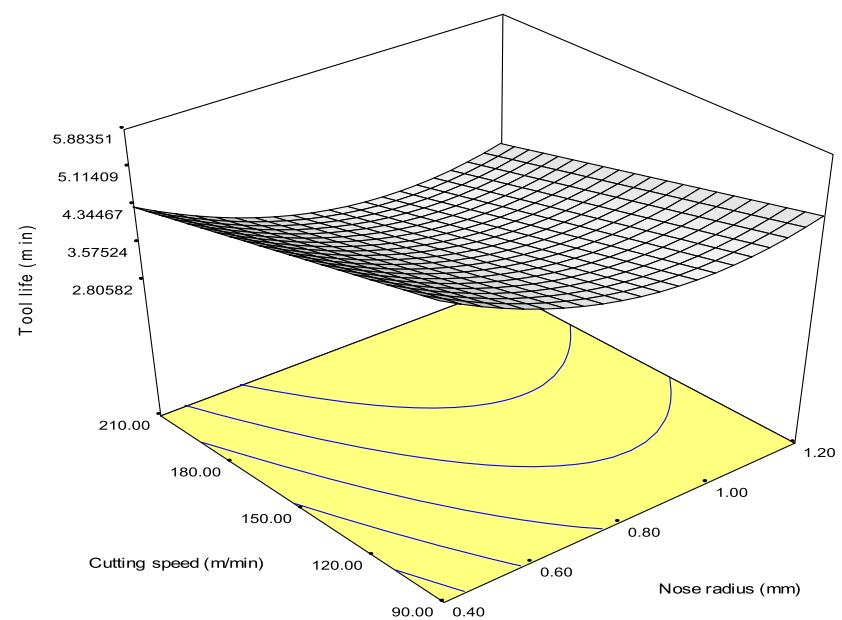

(c): Influence of Cutting Speed and Nose Radius on Tool Life

Fig. 7 a Influence of Cutting Speed and Feed on Tool Life. $\mathbf{b}$ Influence of Cutting Speed and Depth of Cut on Tool Life. c Influence of Cutting Speed and Nose Radius on Tool Life. a, b, c 3D Surface graph for Tool Life (min) 
Table 9 Validation of Face Centered Central Composite Design

\begin{tabular}{llccc}
\hline Ex & Response & AA7075/15wt\%SiC $(20-40 \mu \mathrm{m})$ composites & Model value & \% change \\
\cline { 3 - 5 } & & Exp value & 2.84 & 7.6 \\
\hline 1 & Surface roughness (microns) & 2.91 & 3.4 & 8.8 \\
\hline
\end{tabular}

$2.050 \mu \mathrm{m}$ and tool life is $6.52 \mathrm{~min}$. Multi response optimization of both surface roughness and tool life has resulted in some increase in surface roughness and decrease in tool life. This has been calculated as under;

The \% increase in surface roughness due to multi response optimization, as compared to single objective optimization $=\frac{2.088-2.050}{2.088} \times 100=1.81 \%$.

The \% decrease in tool life due to multi response optimization, as compared to single

$$
\text { objective optimization }=\frac{6.72-6.04}{6.72} \times 100=10.11 \%
$$

\section{Discussions}

\section{Microstructure}

$\mathrm{SiC}$ particles were uniformly distributed as seen in SEM. Limited particle clustering was observed in composites formed in a semi-solid state. Reinforcing phase resides in the interglobular spaces. No gravity segregation of particles was observed in partially remelted composites even if holding time is more. This also support in homogeneous spreading of $\mathrm{SiC}$ particles in AA7075 matrix. No porosity was seen in these structures. Hence, these composites have good mechanical properties. Therefore machining experiments were conducted on these composites.

\section{Effect of nose wear on the surface quality of workpiece}

Type of tool wear that affects the nose radius area, also affects the surface roughness of workpiece. Nose wear also takes place in nose area of cutting tool. Therefore nose wear also affect the roughness of the component. But, investigation about the influence of nose wear on the roughness for MMCs is hardly found in literature. Therefore, life of turning tool and roughness of component have been found out to investigate their correlation in turning operation.

\section{Surface roughness}

Surface condition of machined component is mainly affected by cutting speed, feed, depth of cut and nose radius for a given machine tool and work piece set-up. SiC particles in the AA7075/15 wt.\% SiCp (20-40 $\mu \mathrm{m})$ composites are also responsible for production of semicontinuous types of chips. It start with initiation of macro- cracks on free surface of the chips. This results in bend formation, which in turn pull out the $\mathrm{SiC}$ particles and causes creation of small voids on the machined surface. This is also one of the causes of poor surface finish while turning of $\mathrm{Al} / \mathrm{SiC}-\mathrm{MMC}$. Sahin and Sur 2004 was also of the same opinion.

\section{Effect of cutting speed}

Surface roughness is significantly influence by cutting speed. Surface roughness decreases at high cutting speeds (Fig. 6a). Built up edge (BUE) is formed at low speeds. Chip fracture is also fast at low cutting speed, which results in rough surface. $\mathrm{SiC}$ particles do not result in cutting at low speed. SiC particles slides on cutting tool edge and scratch the machined surface. With the increase in speed, the BUE disappears, chip fracture reduces. Hence surface roughness decreases.

\section{Effect of feed and depth of cut}

Surface roughness increases by increase in feed rate (Fig. 6a). When feed is increased, normal loads on tool also increase. This will produce heat which in turn increases roughness. Increased depth of cut creates high normal pressure and capture on rake face. This promotes formation of BUE. Therefore, surface roughness increases with increase in depth of cut (Fig. 6b).

\section{Effect of nose radius}

Chip thickness varies between zero and a maximum value, when tool with large nose radius is used. This try to plough a large portion of the chips rather than shearing it. This ploughing decreases the surface roughness (Fig. 6c). A large nose radius lessens the saw tooth effect of feed marks and appreciably reduces the surface roughness. An excess nose radius is how ever harmful, because it can cause vibration and chatter.

\section{Tool life}

Predominant abrasion was found to be responsible for flank wear. Life of inserts during turning of AA7075/15 wt\% $\mathrm{SiCp}(20-40 \mu \mathrm{m})$ composites is also affected by many parameters. 


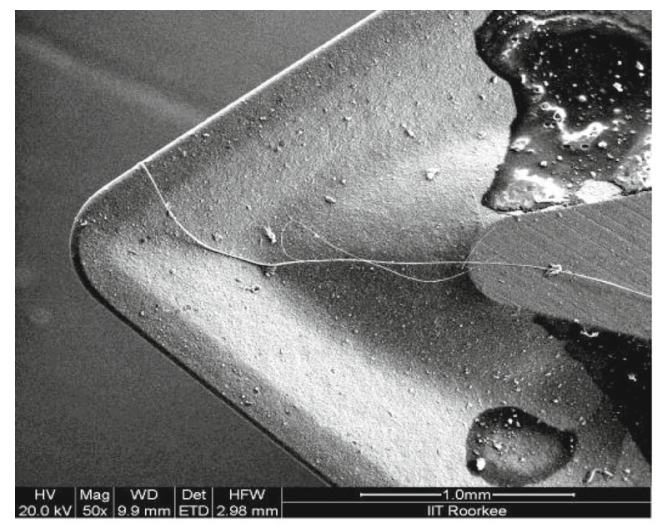

Nose radius $=0.4 \mathrm{~mm}$

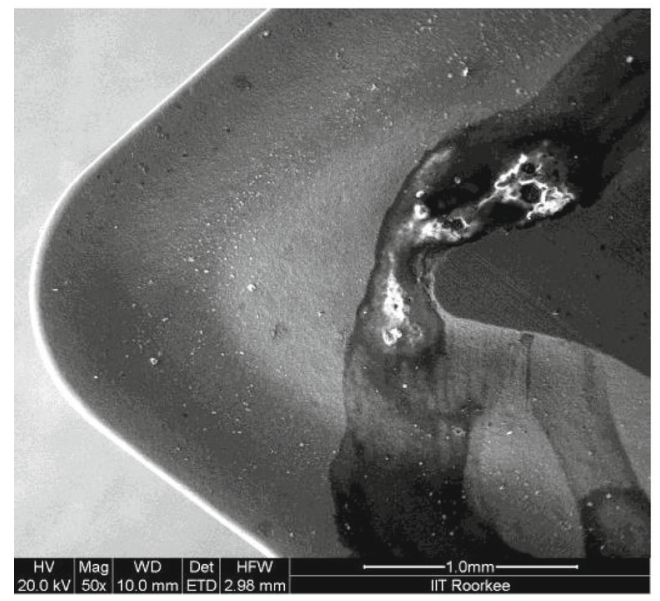

Nose radius $=0.8 \mathrm{~mm}$

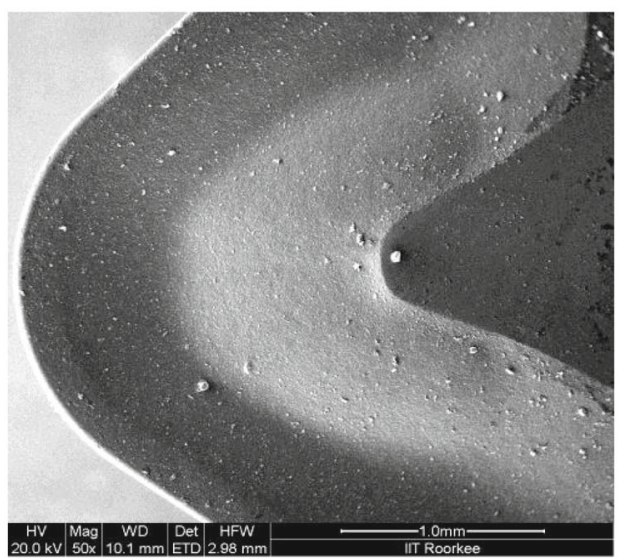

Nose radius $=1.2 \mathrm{~mm}$

Rake face of Insert before turning

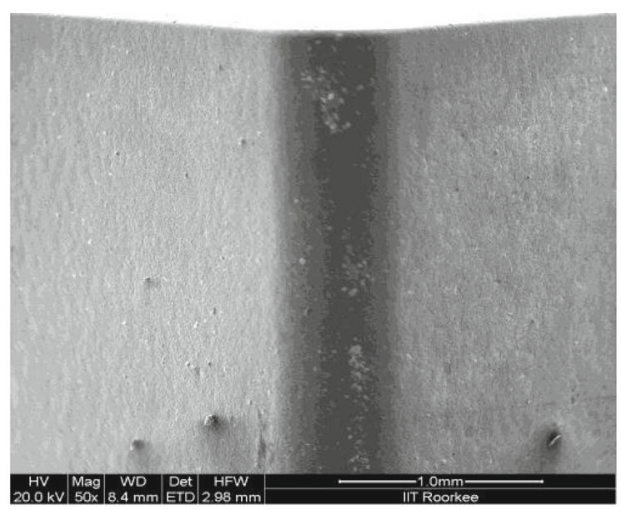

Nose radius $=0.4 \mathrm{~mm}$

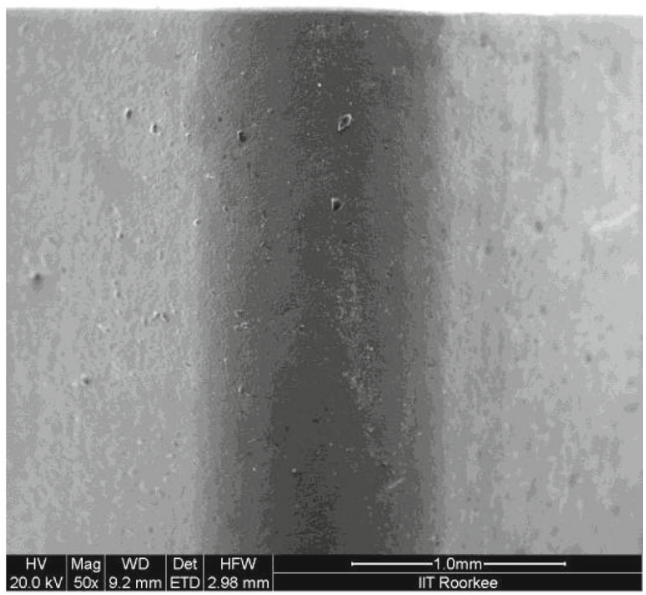

Nose radius $=0.8 \mathrm{~mm}$

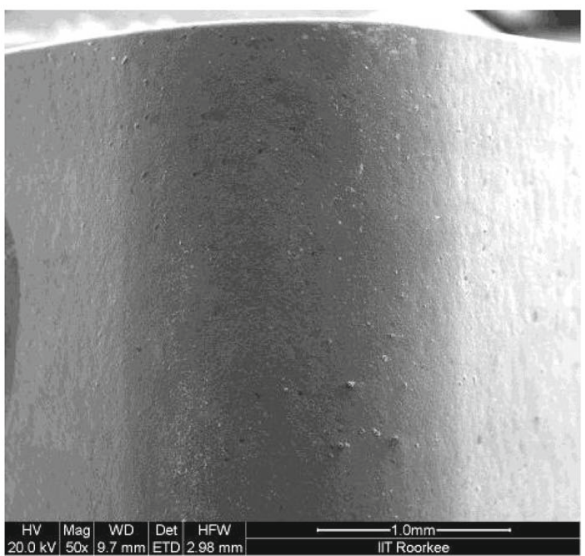

Nose radius $=1.2 \mathrm{~mm}$

Flank face of Insert before turning

Fig. 8 Carbide inserts before machining 


\section{Comparison of Crater Wear of Different Nose Radii}

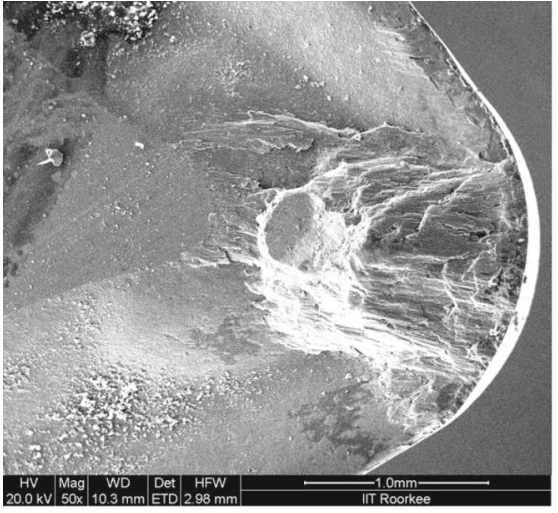

Cutting speed $=90 \mathrm{~m} / \mathrm{min}$, Feed $=0.25 \mathrm{~mm} / \mathrm{rev}$, DOC $=0.6 \mathrm{~mm}$, Nose radius $=1.2 \mathrm{~mm}$

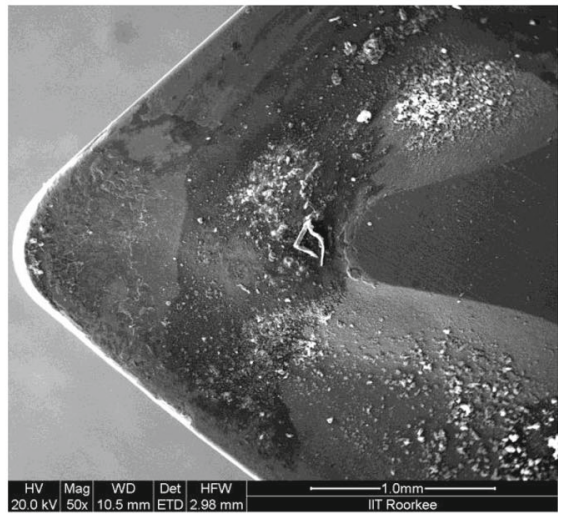

Cutting speed $=90 \mathrm{~m} / \mathrm{min}$, Feed $=0.25 \mathrm{~mm} / \mathrm{rev}$, $\mathrm{DOC}=0.6 \mathrm{~mm}$, Nose radius $=0.4 \mathrm{~mm}$

\section{Comparison of Flank Wear of Different Nose Radii}

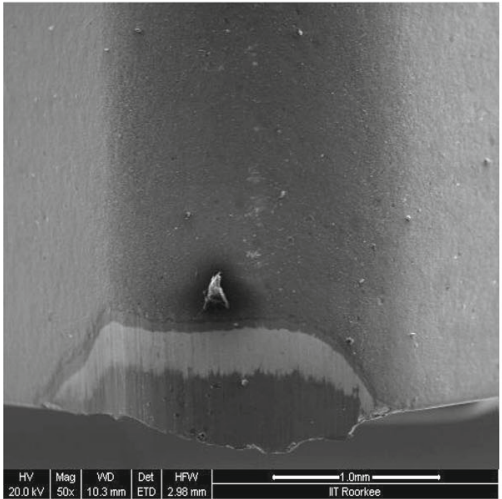

Cutting speed $=90 \mathrm{~m} / \mathrm{min}$, Feed $=0.25 \mathrm{~mm} / \mathrm{rev}$, $\mathrm{DOC}=0.6 \mathrm{~mm}$, Nose radius $=1.2 \mathrm{~mm}$

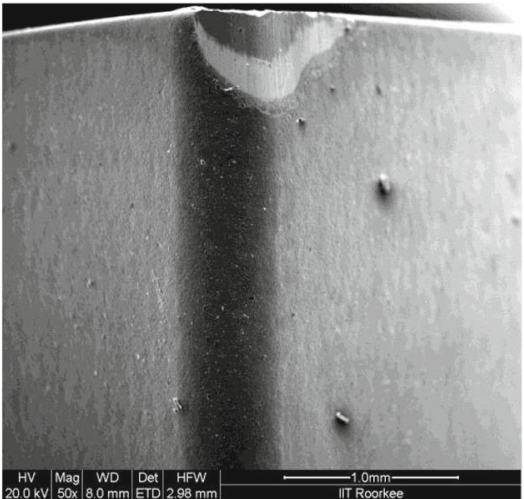

Cutting speed $=90 \mathrm{~m} / \mathrm{min}$, Feed $=0.25 \mathrm{~mm} / \mathrm{rev}$, $\mathrm{DOC}=0.6 \mathrm{~mm}$, Nose radius $=0.4 \mathrm{~mm}$

Fig. 9 Carbide inserts of different Nose Radius after machining

\section{Effect of cutting speed}

Friction between the tool and component is responsible for tool wear. High turning speed would compel the $\mathrm{SiC}$ particles to scrape the tool. Continuous impact will vibrate the tool violently. It will result in breaking of the tool. Therefore tool life will reduce (Fig. 7a). Hence turning is to be done at lower speed. At lower cutting speed, the machining time may be lengthened but tool life is more. But machining efficiency is less and the machined quality is poor.

\section{Effect of feed and depth of cut}

Tool life decrease due to increase of feed and depth of cut (Fig. 7a \& b). If the feed is lower, less number of $\mathrm{SiC}$ particles will be in contact with the tool, hence tool life will be longer. When depth of cut is more, the tool has a

Table 10 Constraints for Multi Objective Optimization of Cutting parameters

\begin{tabular}{|c|c|c|c|c|c|c|}
\hline Response & Constraint & Lower limit & Upper limit & Lower weight & Upper weight & Importance \\
\hline Cutting speed(m/min) & In range & 90 & 210 & 1 & 1 & 3 \\
\hline Feed $(\mathrm{mm} / \mathrm{rev})$ & In range & 0.15 & 0.25 & 1 & 1 & 3 \\
\hline Depth of Cut (mm) & In range & 0.2 & 0.6 & 1 & 1 & 3 \\
\hline Nose radius (mm) & In range & 0.4 & 1.2 & 1 & 1 & 3 \\
\hline Surface roughness $(\mu \mathrm{m})$ & Minimize & 2.113 & 4.754 & 1 & 1 & 4 \\
\hline Tool life (min) & Maximize & 0.6 & 6.5 & 1 & 1 & 2 \\
\hline
\end{tabular}


Table 11 Multi Objective Optimization Solutions

\begin{tabular}{llllllll}
\hline $\begin{array}{l}\text { Solution } \\
\text { no }\end{array}$ & $\begin{array}{l}\text { Cutting speed }(\mathrm{m} / \\
\mathrm{min})\end{array}$ & $\begin{array}{l}\text { Feed } \\
(\mathrm{mm})\end{array}$ & $\begin{array}{l}\text { Depth of cut } \\
(\mathrm{mm})\end{array}$ & $\begin{array}{l}\text { Nose radius } \\
(\mathrm{mm})\end{array}$ & $\begin{array}{l}\text { Surface roughness } \\
(\mu \mathrm{m})\end{array}$ & $\begin{array}{l}\text { Tool life } \\
(\mathrm{min})\end{array}$ & \begin{tabular}{l} 
Desirability Selection \\
\hline 1
\end{tabular} \\
\hline 148.05 & 0.16 & 0.23 & 0.40 & 2.551 & 6.04 & 0.877 & Selected \\
2 & 146.9 & 0.16 & 0.23 & 0.40 & 2.561 & 6.06 & 0.877 \\
3 & 152.89 & 0.16 & 0.23 & 0.40 & 2.535 & 6.00 & 0.877 \\
4 & 143.87 & 0.16 & 0.23 & 0.40 & 2.570 & 6.09 & 0.877 \\
5 & 138.50 & 0.16 & 0.22 & 0.40 & 2.582 & 6.12 & 0.877 \\
\hline
\end{tabular}

larger length for cutting. Hence tool wear would be more. For this reason lower value of depth of cut, is to be taken for longer tool life.

\section{Effect of nose radius}

Tool life decreases with increase of nose radius (Fig. 7c). When nose radius is more, part of the tool cutting edge, in contact with the composite will increase. Because of this large number of $\mathrm{SiC}$ particles come in contact with tool edge and abrade the tool, which results in reduction of tool life.

\section{Effect of nose radius on the tool wear progression}

Impact of nose radius on progress of tool wear is shown in Fig. 9. Flank wear increases with increase in radius of tool. When large nose radius tool is used for turning, chip thickness varies between zero to maximum. This tends to plough major portion of the chips instead of shearing it. Ploughing leads to high stresses and distortion of the layer being cut. Which subsequently causes rise in temperature. Increased cutting edge and volume of tool edge in contact with the material, results in a higher probability of a greater number of abrasive particles coming into contact with, and abrading the cutting tool material. Which leads to severe wear. This is in line with findings of Ibrahim et al. 2004.

Figure 9 represent worn cutting tool when turning AA7075/15wt\%SiC $(20-40 \mu \mathrm{m})$. There are uniform abrasion wear tracks, which represent flank wear. Existence of grooves parallel to the cutting direction along tool flank surface shows the dominance of two body abrasion mechanism. This agrees well with the observations of Xiaoping and Seah 2001. Size and number of parallel grooves enhanced with increase in radius of tool nose. When $\mathrm{SiC}$ slide it is two body abrasion. When $\mathrm{SiC}$ particles roll, wear will mainly depend on plastic distortion of tungsten carbide inserts. Sliding of $\mathrm{SiC}$ particle result in microcutting of the AA7075/15wt.\%SiC composite. Yan and Wang 1993, was also of similar opinion. This leads to creation of parallel grooves that are seen in SEM. Flank wear is because of abrasive action of the $\mathrm{SiC}$ particles. $\mathrm{SiC}$ particle of hardness 2700-3500 HV grind the flank face of cutting tools during turning of AA7075/15wt\% $\mathrm{SiC}$ composites. Weinert 1993, also concluded on same lines.

\section{Major factors affecting tool life}

Abrasion is the main form of tungsten carbide inserts wear for turning of hard $\mathrm{SiC}$ particle-reinforced

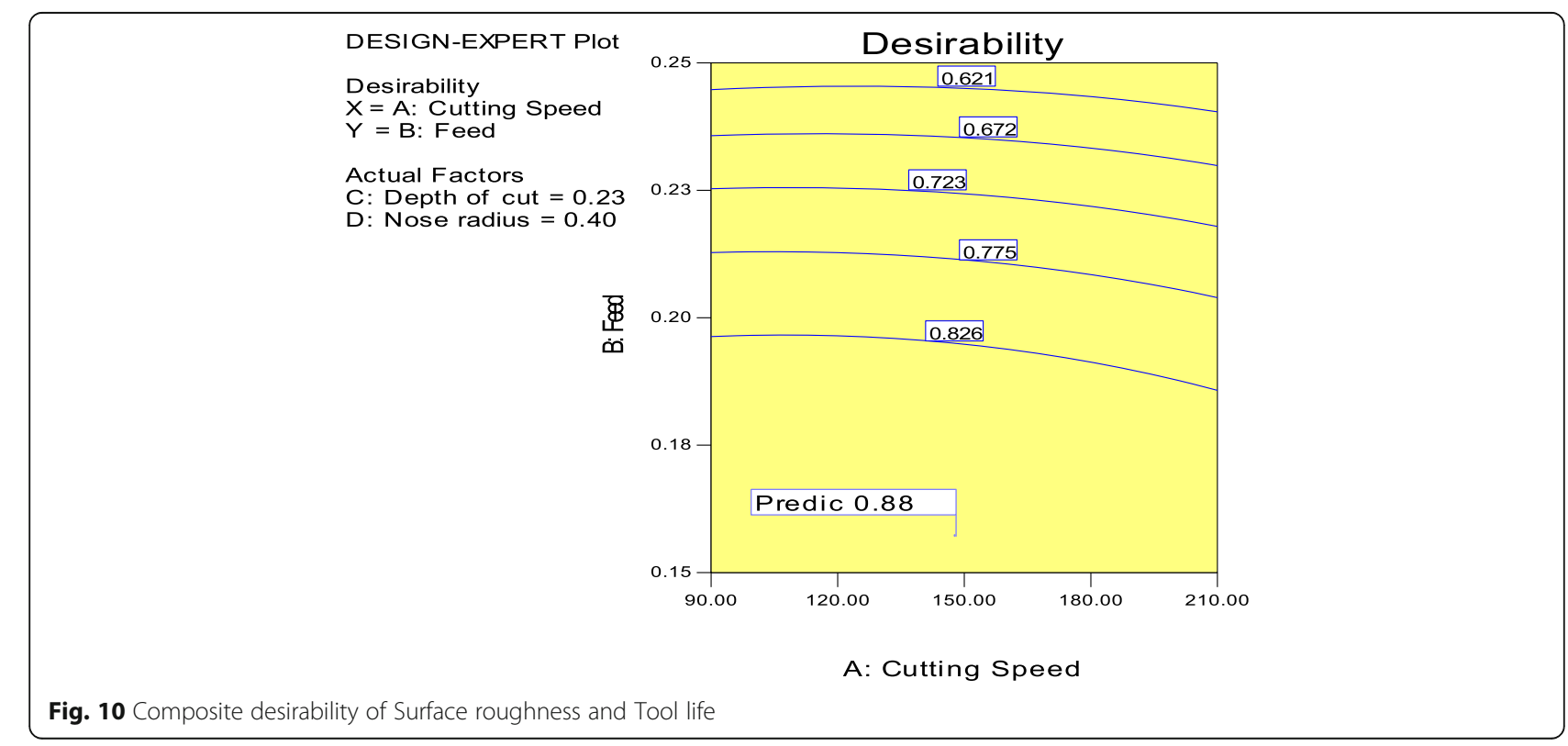



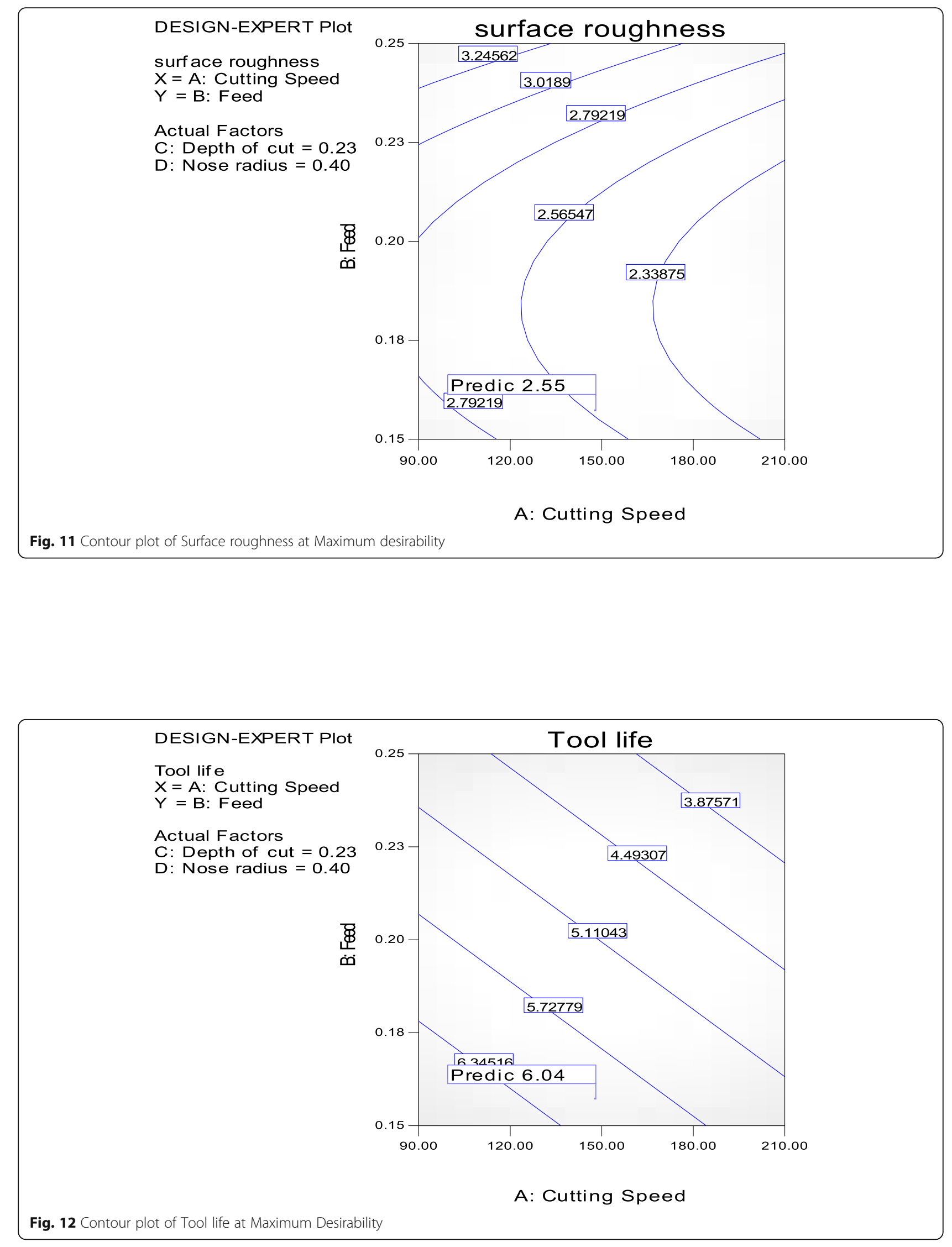
AA7075/15wt\%SiC $(20-40 \mu \mathrm{m})$ composite. Tool life is mainly affected by hardness and weight fraction of $\mathrm{SiC}$ particle in the composites. Experiments have confirmed that tool wear increases with increase in hardness and weight fraction of reinforcement particles. When particles are coarser, tool wear further increases. Which reduces the tool life. Our findings are similar to that of Quigley et al. 1994.

\section{Conclusions}

Nose radius and machining parameters play important role for surface roughness of composite and life of tool during turning. Following are the conclusions of this research work.

1. Depth of cut and tool nose radius were main factors affecting surface roughness. Increase in cutting load to insert edge as the higher depth of cut was used, created more severe plastic deformation resulting in a higher surface roughness. Larger tool nose radius $(1.2 \mathrm{~mm})$ created much lower surface roughness in comparison to smaller tool nose radius $(0.4 \mathrm{~mm})$. This was ascribed to increase in contact length between the insert and component, which reduced residual height of feed marks.

2. Tool life of tungsten carbide inserts reduced with the increase in cutting speed. Increase in feed sharply reduces the tool life of inserts. This was because at higher feed more number of $\mathrm{SiC}$ particles come in contact with insert. The rise in depth of cut first increases then reduces the tool life of tungsten carbide inserts in turning of AA7075/ $15 \mathrm{wt} . \% \mathrm{SiC}$. Tool life decreases as nose radius increases. Tool life was the maximum at nose radius of $0.4 \mathrm{~mm}$.

3. The main mechanism of tool wear in turning of AA7075/15wt.\%SiC composite are two-body and three-body abrasion. The abrasive wear of the tungsten carbide rises when the nose radius increases. This reduces tool life.

4. Considering single objective optimization of cutting parameters the value of surface roughness obtained is $2.088 \mu \mathrm{m}$ and tool life is $6.72 \mathrm{~min}$.

5. Multi response optimization of surface roughness as well as tool life, will naturally result in some compromise, as both the responses are to be optimized simultaneously. Multi response optimized values of surface roughness and tool life are $2.551 \mu \mathrm{m}$ and $6.04 \mathrm{~min}$. This results $1.81 \%$ increase in surface roughness and $10.11 \%$ decrease in tool life. The optimum values of cutting speed, feed, depth of cut and nose radius are $148.05 \mathrm{~m} / \mathrm{min}$, $0.16 \mathrm{~mm} / \mathrm{rev}, 0.23 \mathrm{~mm}$ and $0.40 \mathrm{~mm}$ respectively after multi response optimization.

\section{Acknowledgements}

Not applicable.

\section{Author's contributions}

Paper is by a single author. So he is only the contributor. The author(s) read and approved the final manuscript.

Funding

No funding was provided/received for this research work.

Availability of data and materials

There is no separate data associated.

\section{Competing interests}

There are no competing interests as paper is by a single author.

Received: 4 February 2020 Accepted: 22 July 2020

Published online: 02 August 2020

\section{References}

Benardos PG, Vosniakos GC (2003) Predicting surface roughness in machining: a reviw. Int J Machine Tools Manuf 43:833-844

Bhushan RK (2013) Optimization of cutting parameters for minimizing power consumption and maximizing tool life during machining of $\mathrm{Al}$ alloy $\mathrm{SiC}$ particle composites. J Cleaner Production 39:242-254

Bhushan RK, Kumar S (2011) Influence of SiC particles distribution and their weight percentage on 7075 Al alloy. J Mater Eng Perform 20(2):317-323

Brown I, Schoop J (2020) The effect of cutting edge geometry, nose radius and feed on surface integrity in finish turning of Ti-6Al4V. CIRP. 87:142-147

Choudhury SK, Bartarya G (2003) Role of temperature and surface finish in predicting tool wear using neural network and design of experiments. Int J Mach Tools Manuf 43:747-753

Dimla DE (2000) Sensor signals for tool wear monitoring in metal cutting operations-a review of methods. Int J Mach Tools Manuf 40:1073-1098

Hua Y, Liu Z (2018) Effects of cutting parameters and tool nose radius on surface roughness and work hardening during dry turning Inconel 718. Int J Adv Manuf Technol 96:2421-2430

Ibrahim C, Turker M, Seker U (2004) Evaluation of tool Wear when machining SiC reinforced Al-2014 alloy matrix composites. Mater Design 25:251-255

ISO 3685 (1993) Tool-life testing with single-point turning tools, 2nd edn. International Organisation for Standardisation, Geneva

ISO 4287 (1997) Geometrical Product Specifications (GPS) —Surface Texture: Profile Method-Terms, Definitions and Surface Texture Parameters. International Organisation for Standardisation, Geneva

Jurkovic J, Korosec M, Kopac J (2005) New approach in tool wear measuring technique using CCD vision system. Int J Mach Tools Manuf: 45(9):1023-1030

Kassim S Al-Rubaie, Yoshimura Humberto N, Biosali de Mello Jose Daniel (1999) Two body abrasive wear of Al-SiC composites.Wear, 233-235:444-4.

Kwon Y, Fischer GW (2003) A novel approach to quantifying tool wear and tool life measurements for optimal tool management. Int J Mach Tools Manuf 43: 359-368

Mannan MA, Kassim AA, Jing M (2000) Application of image and sound analysis techniques to monitor the condition of cutting tools. Pattern Recogn Lett 21: 969-979

Moon HK (1990) Rheological behaviour and microstructure of ceramic particulate - aluminium alloy composites. PhD Thesis. MIT, Cambridge

Myers RH, Montgomery DC (1995) Response surface methodology process and product optimization using design experiments. Wiley, USA

Panda A, Das SR, Dhupal D (2020) Machinability investigation and sustainability assessment in FDHT with coated ceramic tool. Steels Composite Struct 34(5): 681-698

Pavel R, Marinescu J, Deis M, Pillar J (2005) Effect of tool wear on surface finish for a case of continuous and interrupted hard turning. J Mater Process Technol 170:341-349

Quigley O, Monaghan J, Reilly PO (1994) Factors affecting the machinability of an Al/SiC metal matrix composite. J MaterProcess Technol 43:21-36

Risbood KA, Dixit US, Sahasrabudhe AD (2003) Prediction of surface roughness and dimensional deviation by measuring cutting forces and vibrations in turning process. J Mater Process Technol 132:203-214

Sahin Y, Sur G (2004) The Effect of A1203, TIN and Ti(C,N) Based CVD coatings on tool wear in machining metal matrix composites. Surf Coat Technol 179:349-355 
Shah D, Bhavsar S (2020) Effect of tool nose radius and machining parameters on cutting force, cutting temperature and surface roughness - an experimental study of Ti-6Al-4V (ELI). Mater Today: Proc 22:1977-1986

Stephenson DA, Agapiou JS (1997) Metal Cutting Theory and Practice. Marcel Dekke, Inc., New York ISBN: 0-8247-9579-2(1997)641-643

Suresh PVS (2002) A genetic algorithmic approach for optimization of surface roughness prediction model. Int J Machine Tools Manufacture 42:675-680

Weinert K (1993) A consideration of tool wear mechanism when machining metal matrix composites. Ann CIRP 42(1):95-98

Wong YS, Nee AYC, Li XQ, Riesdorf C (1997) Tool condition monitoring using laser scatter pattern. J Mater Process Technol 63:205-210

Xiaoping L, Seah WKH (2001) Tool wear acceleration in relation to Workpiece reinforcement percentage in cutting of metal matrix composites. Wear. 247: $161-171$

Yan B-H, Wang C-C (1993) Machinability of SiC particle reinforced aluminium alloy composite material. Light Metal 43(4):187-192

Zhao T, Zhou JM, Bushlya V, Ståh JE (2017) Effect of cutting edge radius on surface roughness and tool wear in hard turning of AISI 52100 steel. Int J Adv Manuf Technol 91:3611-3618

\section{Publisher's Note}

Springer Nature remains neutral with regard to jurisdictional claims in published maps and institutional affiliations.

\section{Submit your manuscript to a SpringerOpen ${ }^{\circ}$ journal and benefit from:}

- Convenient online submission

- Rigorous peer review

- Open access: articles freely available online

- High visibility within the field

- Retaining the copyright to your article

Submit your next manuscript at $\boldsymbol{\triangleright}$ springeropen.com 